УДК: 378.1:005.336.2

DOI: 10.26697/ijes.2018.3-4.04

\section{Сучасні аспекти управлінської компетентності керівників закладів вищої освіти}

Професор Долгальова Олена ${ }^{1}$, старший викладач Єщенко Марина ${ }^{1}$

${ }^{1}$ Донбаська національна академія будівництва $i$ архітектури, Украӥна

\section{Резюме}

Вступ: Сучасний керівник закладу вищої освіти це не просто посада, а й велике педагогічне мистецтво й майстерність. Діяльність керівника будь-якого колективу складна й відповідальна, але в ректора - особлива місія, яка потребує всебічних знань, досконалого володіння наукою управління та професійної культури. Розглянуто поняття “компетентність” керівника.

Результати: У сучасному суспільстві освіта стає одним із визначальних чинників динамічного соціально-економічного розвитку країни. Потреба в професіоналізації управлінської діяльності у сфері освіти в останнє десятиріччя стала відчуватися особливо гостро, що й зумовлює актуальність даного дослідження. I важливим $\epsilon$ визнання сучасними керівниками закладів вищої освіти необхідності активно застосовувати наукові засади менеджменту в освіті та менеджменту освітніх інновацій - нової галузі в управлінні соціальнопедагогічними системами, якими є заклади освіти.

Керівнику сучасного навчального закладу доводиться працювати в період оновлення функціональних обов'язків та видів управлінської діяльності, що пов'язаний з конкретно-історичними умовами розвитку країни, розширення сфери знань та умінь в галузі менеджменту освіти та іншими об'єктивними обставинами. Згідно 3 Державною національною програмою "Освіта" однією 3 важливих умов реформування освіти визначено демократизацію управління закладами вищої освіти, яка передбачає широкий розвиток ініціативи, зв'язок з громадськістю, максимальне використання досвіду та потенційних можливостей усіх працівників і вимагає непорушної єдності у функціонуванні державних і громадських органів, яку повинна забезпечити адміністрація ЗВО. Проблемою управління закладами вищої освіти займалось чимало вчених (Л. Даниленко, О. Мармаза, Є. Хриков та інші), проте залишається відкритим питання особливостей “компетентності" керівників закладів вищої освіти у нових економічних умовах. Проблеми набуття компетентностей та створення ефективних механізмів їх запровадження відображено в роботах О. Овчарук, запровадження компетентнісного підходу в освіті розглянуто в роботах Н. Бібік, В. Кальней, В. Лугового та О. Пометун. Аналіз управлінської діяльності керівника навчального закладу в науковій літературі показав, що: - на сучасному етапі відзначається певна інтенсифікація наукових досліджень щодо підвищення результативності управлінської діяльності керівника; - виникають нові і модернізуються діючі принципи, методи, функції управління керівника навчального закладу. Процес модернізації управлінської діяльності керівника залежить від того, наскільки ефективно сучасний керівник впроваджує в управлінську діяльність новітню наукову управлінську інформацію.

Зазначимо, що більшість дослідників розглядає “компетентність" як оцінну категорію, яка характеризує людину як суб'єкта діяльності, іiі здатність успішно виконувати свої повноваження. Відповідно до Державного стандарту, компетентність складається із знань, умінь, досвіду, цінностей i ставлення, що можуть цілісно реалізовуватися на практиці. Згідно з визначенням Міжнародного департаменту стандартів для навчання, досягнення та освіти поняття компетентності визначається як спроможність кваліфіковано здійснювати діяльність, виконувати завдання або роботу. Підвищення професіоналізму управлінської компетентності керівника $3 \mathrm{BO}$ в сучасних умовах стає важливою умовою успішності інноваційних процесів в освіті й має відбуватися в галузі освітнього менеджменту.

\section{Висновки:}

Освіта відіграє визначальну роль у модернізаційних i трансформаційних процесах нинішнього світу, тому сучасна освіта вимагає нових підходів до 㣙 управління. Проблемам удосконалення системи менеджменту освітянською сферою та окремих піi складників приділено особливу увагу у Національній доктрині розвитку освіти, у якій зафіксовані основні напрями модернізації управління освітою, один 3 яких - підвищення компетентності управлінців усіх рівнів.

\section{Інформація про авторів:}

Долгальова Олена Вячеславівна - доктор 3 державного управління, професор, завідувач кафедри менеджменту, Донбаська національна академія будівництва і архітектури, Краматорськ, Україна.

Наукові інтереси: менеджмент підприємства, управління розвитком підприємства, сталий розвиток, підприємництво і малий бізнес; https://orcid.org/0000-0002-7281-2046.

Єщенко Марина Георгіївна - старший викладач, Донбаська національна академія будівництва i архітектури, Краматорськ, Україна.

Наукові інтереси: сталий розвиток, управління персоналом, актуальні проблеми правознавства України, теоретичні та методичні засади використання IКT у навчальному процесі в академіi; https://orcid.org/0000-0001-7467-7899.

Автор-Кореспондент:

Долгальова Олена Вячеславівна

Email Автора-Кореспондента:

elena.dolgaleva21@gmail.com 